\title{
Factors driving the carbon mineralization priming effect in a sandy loam soil amended with different types of biochar
}

\author{
P. Cely ${ }^{1}$, A. M. Tarquis ${ }^{2,3}$, J. Paz-Ferreiro ${ }^{1}$, A. Méndez ${ }^{4}$, and G. Gascó ${ }^{1}$ \\ ${ }^{1}$ Departamento de Edafología. E.T.S.I. Agrónomos. Universidad Politécnica de Madrid, Ciudad Universitaria, \\ 28004 Madrid, Spain \\ ${ }^{2}$ CEIGRAM, Universidad Politécnica de Madrid, Ciudad Universitaria, 28004 Madrid, Spain \\ ${ }^{3}$ Departamento de Matemática aplicada a la Ingeniería Agronómica. Universidad Politécnica de Madrid, Ciudad \\ Universitaria, 28040 Madrid, Spain \\ ${ }^{4}$ Departamento de Ingeniería de Materiales. E.T.S.I. Minas. Universidad Politécnica de Madrid, C/Ríos Rosas no. 21, \\ 28003 Madrid, Spain \\ Correspondence to: G. Gascó (gabriel.gasco@upm.es)
}

Received: 1 March 2014 - Published in Solid Earth Discuss.: 15 March 2014

Revised: 22 May 2014 - Accepted: 22 May 2014 - Published: 30 June 2014

\begin{abstract}
The effect of biochar on the soil carbon mineralization priming effect depends on the characteristics of the raw materials, production method and pyrolysis conditions. The goal of the present study is to evaluate the impact of three different types of biochar on physicochemical properties and $\mathrm{CO}_{2}$ emissions of a sandy loam soil. For this purpose, soil was amended with three different biochars (BI, BII and BIII) at a rate of $8 \mathrm{wt} \%$ and soil $\mathrm{CO}_{2}$ emissions were measured for 45 days. $\mathrm{BI}$ is produced from a mixed wood sieving from wood chip production, BII from a mixture of paper sludge and wheat husks and BIII from sewage sludge. Cumulative $\mathrm{CO}_{2}$ emissions of biochars, soil and amended soil were well fit to a simple first-order kinetic model with correlation coefficients $\left(r^{2}\right)$ greater than 0.97 . Results show a negative priming effect in the soil after addition of BI and a positive priming effect in the case of soil amended with BII and BIII. These results can be related to different biochar properties such as carbon content, carbon aromaticity, volatile matter, fixed carbon, easily oxidized organic carbon or metal and phenolic substance content in addition to surface biochar properties. Three biochars increased the values of soil field capacity and wilting point, while effects over $\mathrm{pH}$ and cation exchange capacity were not observed.
\end{abstract}

\section{Introduction}

Biochar is a carbonaceous material obtained from biomass pyrolysis or gasification processes. Biochar production emits carbon dioxide and other greenhouse gases, but combined with proper waste disposal or biofuel production it offers a practical way of mitigating global warming (Barrow, 2012). For many years now, it has been researched as a significant means of improving soil productivity, carbon storage, and the filtration of soil percolating water (Lehmann and Joseph, 2009). In fact, land degradation is a worldwide phenomenon that affects soil quality, water resources, human societies and economic development (Zhao et al., 2013; Omutu et al., 2014). Biochar as a source of organic matter (Paz Ferreiro and Fu, 2014) can improve the quality of soils in crop and rangeland (Yan-Gui et al., 2013) and then the development of societies (Srinivasarao et al., 2014) and reduce the impact of climate change (Barbera et al., 2013).

Nowadays, biochar production is attracting more attention because it is a safer method of organic waste management. Many types of biomass can be transformed into biochar, including wood wastes, crop residues, switch grass, wastewater sludge or deinking sludges (Méndez et al., 2012; PazFerreiro et al., 2014; Sohi et al., 2010). If enough farmers, larger agricultural enterprises, biofuel producers, and waste treatment plants established biochar production methods, it 
could reduce $\mathrm{CO}_{2}$ emissions related to agriculture while improving soil productivity.

Biochar is a highly recalcitrant organic material, with a long-term stability in soil, which is on the scale of millennia or longer (Kuzyakov et al., 2014). The response that soil exhibits to biochar addition has global consequences for carbon cycling. Depending on the interaction between soil and biochar, the ecosystem could become a sink or source of carbon.

The term priming effect refers to increases or decreases in the mineralization of native soil organic matter due to the addition of substrates and has been observed in many studies, both in the field and under laboratory conditions (PazFerreiro et al., 2012; Zavalloni et al., 2009; Zimmerman et al., 2011). While it is generally regarded that biochar addition results in a reduction in soil carbon emissions from the soil, the fact is that the results are biochar and soil specific. Indeed, previous works have shown that there is no clear trend in $\mathrm{CO}_{2}$ emissions after biochar application. For example, Zimmerman et al. (2011) found that carbon mineralization was generally less than expected (negative priming) for soils combined with biochars produced at high temperatures $\left(525\right.$ and $650^{\circ} \mathrm{C}$ ) and from hard woods, whereas carbon mineralization was greater than expected (positive priming) for soils combined with biochars produced at low temperatures $\left(250\right.$ and $400{ }^{\circ} \mathrm{C}$ ) and from grasses, particularly during the early incubation stage and in soils of lower organic carbon content. Luo et al. (2011) used biochar from plant residues and found during the first 13 days of incubation experiment that biochar obtained at $350^{\circ} \mathrm{C}$ causes a large positive priming effect, while biochar prepared at higher temperatures $\left(700^{\circ} \mathrm{C}\right)$ caused a relatively small positive priming effect. These authors hypothesized that the priming effect was probably caused by labile organic matter remaining in the biochar after pyrolysis, which in turn activated the soil microorganism. Jones et al. (2011) hypothesized that the increment in soil respiration is due to a different mechanism than changes in soil physical properties (bulk density, porosity, moisture); biological breakdown of organic carbon released from the biochar; abiotic release of inorganic carbon contained in the biochar and a stimulation of decomposition of soil organic matter. Zavalloni et al. (2011) have shown that the amount of soil carbon respired was similar between the control and soil treated with biochar from coppiced woodland pyrolysis in a short-term incubation experiment. Also, Wardle et al. (2008) reported a priming effect from a boreal soil after biochar addition, although the results of this experiment have been disputed by others (Lehmann and Sohi, 2008). If a strong positive priming effect occurs after biochar addition to the soil, then the beneficial effects attained by biochar addition to the soil becomes mitigated. Furthermore, although the use of biochar measuring soil respiration has been evaluated (Méndez et al., 2012; Zimmerman et al., 2011), fewer studies have studied the role of biochar addition of native soil organic matter (Zimmermann et al., 2011; Cross and Sohi, 2011; Gascó et al., 2012). For example, Gascó et al. (2012) observed using thermal methods that there is a degradation of more complex structures after application of a sewage sludge biochar to a Haplic Cambisol. The final chemical composition and physical properties of biochar, and thus its potential for having a positive or negative priming effect, depends on the characteristics of the raw materials, production method and pyrolysis conditions. Different studies has been performed in order to study the influence of feedstock, production method and pyrolisis temperature on biochar properties and uses (Calvelo Pereira et al., 2011; Méndez et al., 2012; Zimmermann et al., 2011; Paz-Ferreiro et al., 2014).

In the present work, three different biochars were used in order to study their influence on soil properties and $\mathrm{CO}_{2}$ emissions. Biochars were obtained from pyrolysis of different types of biomass: mixed wood sievings from wood chip production, paper sludge and wheat husks and sewage sludge at temperatures between 500 and $620^{\circ} \mathrm{C}$ using slow pyrolysis processes.

\section{Materials and methods}

\subsection{Soil selection and characterization}

The selected soil was taken from the northeast of Toledo (Spain) and the soil was air-dried, crushed and sieved through a $2 \mathrm{~mm}$ mesh prior to analysis. The initial $\mathrm{pH}$ and electrical conductivity (EC) were determined with a soil : water ratio of $1: 2.5\left(\mathrm{~g} \mathrm{~m} \mathrm{~L}^{-1}\right)$ using a Crison micro-pH 2000 (Thomas et al., 1996) and a Crison 222 conductivimeter (Rhoades, 1996) respectively. CEC was determined by $\mathrm{NH}_{4} \mathrm{OAc} / \mathrm{HOAc}$ at pH 7.0 (Sumner and Miller, 1996). Total organic matter (TOM) was determined using the dry combustion method at $540{ }^{\circ} \mathrm{C}$ (Nelson and Sommers, 1996). Soil metal content was determined using a Perkin Elmer 2280 atomic absorption spectrophotometer after sample extraction by digestion with concentrated $\mathrm{HCl} / \mathrm{HNO}_{3}$ following method 3051a (USEPA, 1997). Soil texture was determined following the methodology of Bouyoucos (1962). These analyses were performed in triplicate.

\subsection{Biochar characterization}

Three different biochar samples were selected and used for the present work: biochar I (BI) was produced by Swiss Biochar (Lausanne, Switzerland) from mixed wood sievings from wood chip production at $620^{\circ} \mathrm{C}$; biochar II (BII) was produced by Sonnenerde (Austria) from a mixture of paper sludge and wheat husks at $500^{\circ} \mathrm{C}$; and biochar III (BIII) was produced by Pyreg (Germany) from sewage sludge at $600^{\circ} \mathrm{C}$. The pyrolisis duration was $20 \mathrm{~min}$ in all cases. All biochar samples were produced using Pyreg500-III pyrolysis (Germany) units that can work until $650^{\circ} \mathrm{C}$ in a continuous process. 
The $\mathrm{pH}, \mathrm{EC}, \mathrm{CEC}$ and metal content in biochars were performed as in Sect. 2.1. Proximate analysis was determined by thermogravimetry using Labsys Setaram equipment. The sample was heated to a temperature of $600^{\circ} \mathrm{C}$ under $\mathrm{N}_{2}$ atmosphere and $30^{\circ} \mathrm{C} \mathrm{min}^{-1}$ heating rate. Humidity was calculated as the weight loss from the initial temperature to $150{ }^{\circ} \mathrm{C}$. The volatile matter (VM) was determined as the weight loss from $150{ }^{\circ} \mathrm{C}$ to $600^{\circ} \mathrm{C}$ under $\mathrm{N}_{2}$ atmosphere. At this temperature, air atmosphere was introduced and fixed carbon (FC) was calculated as the weight produced when the final sample was burned. The ashes were determined as the final weight of the samples. The content in $\mathrm{C}, \mathrm{H}, \mathrm{N}$ and $\mathrm{S}$ was analyzed by an elemental microanalyzer LECO CHNS932 and the oxygen content was determined by difference. Biochar nitrogen adsorption analysis to determine BET surface area was carried out at $77 \mathrm{~K}$ in a Micromeritics Tristar 3000. Also, biochar $\mathrm{CO}_{2}$ adsorption analysis to determine both $\mathrm{CO}_{2}$ micropore surface area and monolayer capacity was performed at $273 \mathrm{~K}$ in a ASAP $2020 \mathrm{~V} 3.01$.

Finally, biochar phenolic substances were determined using a Folin-Ciocalteu reagent (Martín-Lara et al., 2009).

\subsection{Treatments and soil respiration}

The selected soil (S) was amended with the three biochar samples at $8 \mathrm{wt} \%(\mathrm{~S}+\mathrm{BI}, \mathrm{S}+\mathrm{BII}, \mathrm{S}+\mathrm{BIII})$ and mixtures were incubated at constant temperature $\left(28 \pm 2{ }^{\circ} \mathrm{C}\right)$ and humidity (60\% FC) for 45 days. Additionally, it was studied if the application of the different amendments had an additive or synergistic effect in the soil (priming effect); in this way each biochar (BI, BII, BIII) was incubated individually in the experimental conditions.

Each sample $(100 \mathrm{~g})$ was introduced into a $1 \mathrm{~L}$ airtight jar and the $\mathrm{CO}_{2}$ produced during incubation was collected in $50 \mathrm{~mL}$ of a $0.3 \mathrm{~N} \mathrm{NaOH}$ solution, which was then titrated using $0.3 \mathrm{~N} \mathrm{HCl}$ after the $\mathrm{BaCl}_{2}$ precipitation of the carbonates. All treatments were performed in triplicate.

Organic carbon oxidized with dichromate from initial and final biochars was determined by the Walkley-Black method (Nelson and Sommers, 1996).

After incubation time, the next soil properties were determined: pH, EC, CEC, field capacity (FC), wilting point (WP) and available water (AW). pH, EC and $\mathrm{CEC}$ were determined as in Sect. 2.1. Field capacity (FC) and wilting point (WP) were determined as the soil moisture content at $33 \mathrm{kPa}$ (FC) and $1500 \mathrm{kPa}$ (WP) (Richards, 1954). Available water (AW) was calculated as the difference between FC and WP. All analyses were performed in triplicate.

In addition, thermal analysis (TG, dTG and DTA) of soil was performed in a thermogravimetric equipment Labsys Setaram. About $50 \mathrm{mg}$ of each sample were heated at $15^{\circ} \mathrm{C} \mathrm{min}{ }^{-1}$ until $850^{\circ} \mathrm{C}$ in the air atmosphere using a flow rate of $40 \mathrm{~mL} \mathrm{~min}^{-1}$.

\subsection{Mineralization model}

The cumulative mineralization data were fitted to a first-order kinetic model, which is widely used to model soil respiration data (Méndez et al., 2013). The kinetic model used to calculate the evolved $\mathrm{CO}_{2}-\mathrm{C}$ soil is described as follows:

$Y=C t^{m}$

where $Y$ is the cumulative $\mathrm{CO}_{2}-\mathrm{C}\left(\mathrm{mg} \mathrm{CO}_{2}-\mathrm{C} 100 \mathrm{~g}^{-1}\right.$ soil), $t$ is the cumulative time of incubation (d), and $C$ and $m$ are the mineralization constants, with $C \cdot m$ representing the initial mineralization rate. The convexity shape of $Y$ in this model is defined mainly by $m$, with $m \leq 1$ and $C \geq 0$. This equation was fitted to describe the $C$ mineralization in $\mathrm{S}$, the biochars (BI, BII and BIII) and the amended soils ( $\mathrm{S}+\mathrm{BI}$, $\mathrm{S}+\mathrm{BII}$ and $\mathrm{S}+\mathrm{BIII})$. The mineralization rate parameters of Eq. (1) were estimated by a non-linear model method, minimizing RMSA.

To quantify the priming effect of the three raw materials, the model was fitted to the experimental data (Experiment) and to the respiration data with the addition of $92 \mathrm{~g}$ of soil with $8 \mathrm{~g}$ of biochars (Addition). Also, $\mathrm{C}_{10}$ was calculated as the evolved $\mathrm{CO}_{2}-\mathrm{C}$ after 10 days according to the model.

\section{Results and discussion}

Table 1 shows the main properties of the soil and three biochars. The soil texture was sandy loam, it had a slightly alkaline $\mathrm{pH}$, the $\mathrm{EC}$ value indicated that the soil has no risk of salinization and soil organic matter content was $6.30 \%$.

With respect to biochars, BI and BII showed basic $\mathrm{pH}$, whereas BIII had a $\mathrm{pH}$ value near 7. Proximate analysis of three biochar samples showed differences in their composition. The ash content of biochars followed the next sequence $\mathrm{BIII}>\mathrm{BII}>\mathrm{BI}$ depending on the feedstock, i.e., $\mathrm{BI}$ is prepared from woodchip, BII from paper sludge and wheat husk and BIII from sewage sludge presenting a higher mineral content. Indeed, BIII had the highest EC and metal content. Biochar metal content did not exceed the limit values for concentrations of metals in soil set up by the European Union (European Community, 1986), with BIII presenting the highest content, which can be explained according to its origin. All biochars presented a similar CEC, which can be related to the comparable temperature of preparation. The volatile matter content of BI and BIII was similar and lower than that of BII. Fixed carbon of BI was significantly higher than that of BII and BIII. Combining VM and FC, the ratio $\mathrm{FC} /(\mathrm{FC}+\mathrm{VM})$ could be indicative of the carbon stability. According to this, BI was a very recalcitrant carbon material, whereas BIII showed the lowest ratio. The molar $\mathrm{H} / \mathrm{C}$ ratio was used as an indicator of the degree of aromatization. This ratio shows the sequence $\mathrm{BI}<\mathrm{BII}<\mathrm{BIII}$. The $\mathrm{O} / \mathrm{C}$ ratio was indicative of the degree of carbonization following the same trend as the $\mathrm{H} / \mathrm{C}$ ratio, $\mathrm{BI}<\mathrm{BII}<\mathrm{BIII}$. According to 
Table 1. Main properties of the soil (S) and biochars.

\begin{tabular}{|c|c|c|c|c|}
\hline & $S$ & $\mathrm{BI}$ & BII & BIII \\
\hline $\mathrm{pH}(1: 2.5)$ & $7.66 \pm 0.10$ & $10.19 \pm 0.12$ & $9.40 \pm 0.19$ & $7.66 \pm 0.13$ \\
\hline $\mathrm{EC}\left(1: 2.5\left(\mathrm{dS} \mathrm{m}^{-1}, 25^{\circ} \mathrm{C}\right)\right.$ & $70 \pm 10$ & $1776 \pm 44$ & $2330 \pm 50$ & $3700 \pm 157$ \\
\hline TOM $(\%)$ & $6.30 \pm 0.15$ & $87.71 \pm 0.71$ & $59.90 \pm 0.89$ & $25.15 \pm 0.40$ \\
\hline $\mathrm{CEC}\left(\mathrm{cmol}_{(\mathrm{c})} \mathrm{kg}^{-1}\right)$ & $15.87 \pm 0.25$ & $23.77 \pm 0.36$ & $20.97 \pm 0.24$ & $24.19 \pm 0.30$ \\
\hline $\mathrm{Cd}\left(\mathrm{mg} \mathrm{kg}^{-1}\right)$ & - & $0.43 \pm 0.05$ & $0.72 \pm 0.08$ & $4.98 \pm 0.01$ \\
\hline $\mathrm{Cr}\left(\mathrm{mg} \mathrm{kg}^{-1}\right)$ & - & $21 \pm 2$ & $32 \pm 4$ & $76 \pm 8$ \\
\hline $\mathrm{Cu}\left(\mathrm{mg} \mathrm{kg}^{-1}\right)$ & - & $61 \pm 9$ & $37 \pm 8$ & $406 \pm 25$ \\
\hline $\mathrm{Ni}\left(\mathrm{mg} \mathrm{kg}^{-1}\right)$ & - & $18 \pm 1$ & $30 \pm 1$ & $78 \pm 10$ \\
\hline $\mathrm{Pb}\left(\mathrm{mg} \mathrm{kg}^{-1}\right)$ & - & $4 \pm 1$ & $24 \pm 3$ & $141 \pm 10$ \\
\hline $\mathrm{Zn}\left(\mathrm{mg} \mathrm{kg}^{-1}\right)$ & - & $47 \pm 5$ & $134 \pm 9$ & $1350 \pm 49$ \\
\hline Phenolic substances (mg gallic acid $\mathrm{g}^{-1}$ ) & & $0.93 \pm 0.05$ & $1.01 \pm 0.07$ & $0.49 \pm 0.04$ \\
\hline Sand $(\%)$ & 77.78 & - & - & - \\
\hline Silt $(\%)$ & 17.78 & - & - & - \\
\hline Clay $(\%)$ & 4.44 & - & - & - \\
\hline Soil textural class & Sandy loam & - & - & - \\
\hline $\mathrm{FC}(\%)$ & & $113 \pm 1$ & $122 \pm 1$ & $36 \pm 1$ \\
\hline $\mathrm{WP}(\%)$ & & $52 \pm 1$ & $63 \pm 1$ & $31 \pm 1$ \\
\hline $\mathrm{AW}(\%)$ & & $61 \pm 1$ & $59 \pm 1$ & $5 \pm 1$ \\
\hline BET Surface Area $\left(\mathrm{m}^{2} \mathrm{~g}^{-1}\right)$ & - & 332.138 & 92.6115 & 59.1572 \\
\hline Micropore area $\left(\mathrm{m}^{2} \mathrm{~g}^{-1}\right)$ & - & 305.9972 & 66.9119 & 30.9545 \\
\hline Adsorption average pore width $(\AA)$ & - & 21.2622 & 32.9697 & 77.1478 \\
\hline $\mathrm{CO}_{2}$ micropore surface area $\left(\mathrm{m}^{2} \mathrm{~g}^{-1}\right)$ & & 414.206 & 229.399 & 86.329 \\
\hline $\mathrm{CO}_{2}$ monolayer capacity $\left(\mathrm{cm}^{3} \mathrm{~g}^{-1}\right)$ & & 90.672 & 50.217 & 18.898 \\
\hline \multicolumn{5}{|l|}{ Proximate analysis } \\
\hline $\mathrm{VM}(\%)^{\mathrm{a}}$ & - & 14.88 & 22.43 & 13.68 \\
\hline $\mathrm{FC}(\%)^{\mathrm{b}}$ & - & 77.25 & 42.72 & 12.77 \\
\hline $\operatorname{Ash}(\%)$ & - & 7.87 & 34.85 & 73.55 \\
\hline $\mathrm{FC} /(\mathrm{FC}+\mathrm{VM})$ & - & 0.84 & 0.66 & 0.48 \\
\hline \multicolumn{5}{|l|}{ Elemental analysis } \\
\hline $\mathrm{C}(\%)$ & & 82.00 & 50.75 & 18.45 \\
\hline $\mathrm{H}(\%)$ & & 1.49 & 1.73 & 1.19 \\
\hline $\mathrm{N}(\%)$ & & 0.33 & 1.36 & 2.10 \\
\hline $\mathrm{O}(\%)$ & & 5.76 & 12.08 & 7.69 \\
\hline $\mathrm{H} / \mathrm{C}$ atomic ratio & & 0.018 & 0.034 & 0.064 \\
\hline $\mathrm{O} / \mathrm{C}$ atomic ratio & & 0.070 & 0.238 & 0.417 \\
\hline
\end{tabular}

a VM: Volatile matter.

${ }^{\mathrm{b}}$ FC: Fixed carbon.

previous studies on biochars (Kuhbusch and Crutzen, 1995; Hammes et al., 2006) the $\mathrm{H} / \mathrm{C}$ ratio of $\leq 0.3$ (like BI) indicates a highly condensed aromatic ring system, whereas the $\mathrm{H} / \mathrm{C}$ ratio of $\geq 0.7$ (like BIII) represents a non-condensed structure.

Table 2 shows the changes in $\mathrm{pH}, \mathrm{EC}$ and CEC after the 45 days of the incubation experiment. Instead, biochar pHs were different (Table 1); $\mathrm{pH}$ did not change after biochar application, though $\mathrm{BI}$ and $\mathrm{BII}$ presented $\mathrm{pH} 2$ units higher than soil. Conversely, other studies have shown $\mathrm{pH}$ increments after biochar application. For example, Méndez et al. (2012) observed a pH increment on a Haplic Cambisol after the ad-
Table 2. $\mathrm{pH}$, electrical conductivity (EC), cation exchange capacity of treated soils after the incubation experiment.

\begin{tabular}{llcc}
\hline & $\mathrm{pH}$ & $\mathrm{EC}\left(\mu \mathrm{S} \mathrm{cm}^{-1}\right)$ & $\mathrm{CEC}\left(\mathrm{cmol}_{(\mathrm{c})} \mathrm{kg}^{-1}\right)$ \\
\hline $\mathrm{S}$ & $7.45 \mathrm{ab}$ & $496 \mathrm{a}$ & $15.71 \mathrm{a}$ \\
$\mathrm{S}+\mathrm{BI}$ & $7.68 \mathrm{~b}$ & $535 \mathrm{a}$ & $16.28 \mathrm{a}$ \\
S+BII & $7.47 \mathrm{ab}$ & $624 \mathrm{~b}$ & $16.08 \mathrm{a}$ \\
$\mathrm{S}+\mathrm{BIII}$ & $7.29 \mathrm{a}$ & $764 \mathrm{c}$ & $17.07 \mathrm{a}$ \\
\hline
\end{tabular}

Values in column followed by the same letter are not significantly different ( $P=0.05)$ using the Duncan test.

The number of replicates was 3 for each determination. 
dition of sewage sludge-derived biochar, Kloss et al. (2014) described a slight increment of soil $\mathrm{pH}$ ( 0.3 units) in an acid soil after application of woodchip-derived biochar, and Jien and Wang (2013) observed a significant increase in Ultisol $\mathrm{pH}$ from 3.9 to 5.1 after addition of biochar made from the waste wood of white lead trees, so both biochar and soil composition influence the $\mathrm{pH}$ changes. Biochar addition slightly increased soil EC (Table 1), but the risk of salinization was negligible at the applied dose (USDA, 1999). The increase in soil EC is very common in soils treated with biochar prepared from sludge, which is the case for BII and BIII, as reported in other studies (Hossain et al., 2010 or Méndez et al., 2012). With respect to CEC, biochars did not increase soil CEC, a result according to previous works (Méndez et al., 2012) and which can be related to the low CEC of biochar with respect to soil OM (Lehmann, 2007).

Biochars increased the values of soil FC and WP following the sequence $\mathrm{S}<\mathrm{S}+\mathrm{BIII}<\mathrm{S}+\mathrm{BI} \approx \mathrm{S}+\mathrm{BII}$ for both properties. Also, there was an increment in the AW when the soil was treated by BI and BII. This improvement in water retention is in accordance with the results previously obtained by Méndez et al. (2012), which found the same trend in a soil with a similar sand content treated with biochar prepared for sewage sludge at $600^{\circ} \mathrm{C}$. The higher increment of FC, WP and $\mathrm{AW}$ in $\mathrm{S}+\mathrm{BI}$ and $\mathrm{S}+\mathrm{BII}$ treatments could be related to the higher values of FC and WP of these biochars according to their high surface area and porosity (Table 1).

In the last years, thermal analysis has been proposed as an interesting technique in the characterization of organic matter stabilization processes. Additionally, it has been applied to soil characterization to assess proportions of labile and recalcitrant organic matter (Plante et al., 2009) and to study the evolution of organic matter in amended soils (Barriga et al., 2010; Gascó et al., 2012). Thermal analysis has the advantage of providing information about the chemical characteristics of soil organic matter without any extraction step as all samples were analyzed. Figure 1 shows dTG (Fig. 1a) and DTA (Fig. 1b) of S, S+BI, S+BII and S+BIII samples after the incubation period. Different peaks were observed in Fig. 1; at temperatures lower than $150^{\circ} \mathrm{C}$, water releases were observed, then at temperatures from 200 to $650{ }^{\circ} \mathrm{C}$, oxidation of organic matter takes place. Initially, weight loss corresponds to less humified matter (from 200 to $400^{\circ} \mathrm{C}$ ), whereas the peaks observed at temperatures higher than $400^{\circ} \mathrm{C}$ correspond to more humified organic matter. At temperatures higher than $550^{\circ} \mathrm{C}$ weight loss could be attributed to refractory carbon from biochars and clay decomposition (Gascó et al., 2012).

From the DTA curve, the first endothermic peak could be observed at temperatures lower than $150{ }^{\circ} \mathrm{C}$ due to moisture release from soil samples. Then, two small exothermic peaks could be observed between 200 and $650^{\circ} \mathrm{C}$ due to combustion reactions of soil organic matter. It is established that the first peak was associated with combustion of less humified organic matter, whilst the second one was related to the
Пa)

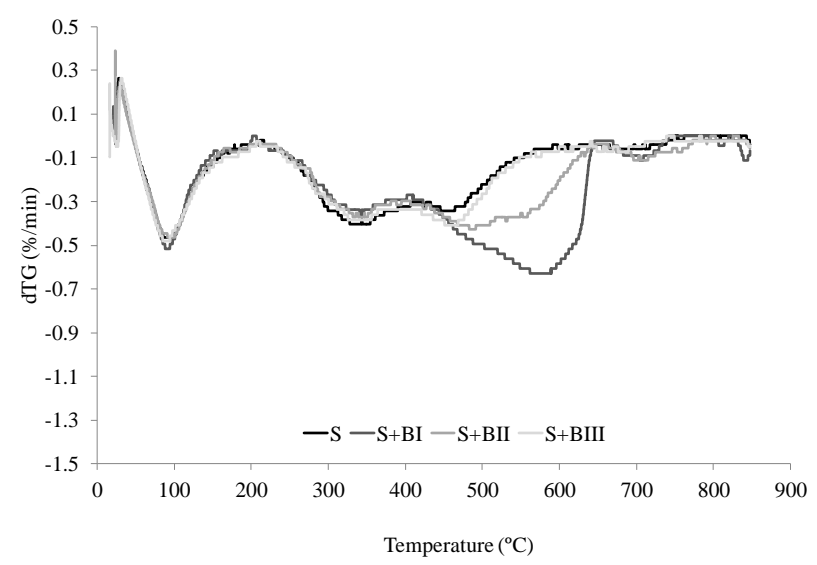

b)

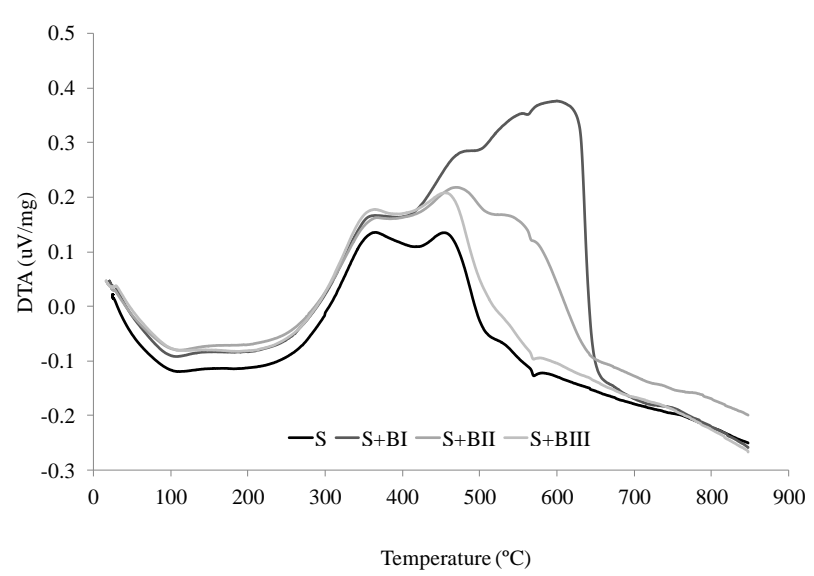

Figure 1. dTG (1.a) and DTA curves (1.b) of soil and soil amended with biochar after the incubation period.

more humified matter. Four samples are shown at $573{ }^{\circ} \mathrm{C}$, the characteristic small endothermic peak due to the quartz $\alpha-\beta$ inversion. Comparison of four samples in Fig. 1a and $b$ shows the influence of different biochars in soil organic matter composition. Biochar addition increases the amount of more humified or thermally stable organic matter following the sequence $\mathrm{S}+\mathrm{BI}>\mathrm{S}+\mathrm{BII}>\mathrm{S}+\mathrm{BIII}$. It was interesting to note that $\mathrm{S}+\mathrm{BIII}$ shows a thermal behavior similar to that of unamended soil $(\mathrm{S})$, indicating a similar organic matter composition to original soil.

With respect to biochar $\mathrm{CO}_{2}$ emissions, these were higher in BI while significant differences between BII and BIII were not found. This fact can be attributed to the elevated TOM of BI (87.71\%) with respect to BII $(59.90 \%)$ and BIII $(25.15 \%)$. In order to explain the similar $\mathrm{CO}_{2}$ emissions of BII and BIII other factors need to be accounted for (Jones et al., 2011). Calvelo Pereira et al. (2011) found that dichromate oxidation reflects the degree of biochar carbonization and could therefore be used to estimate the labile fraction of 


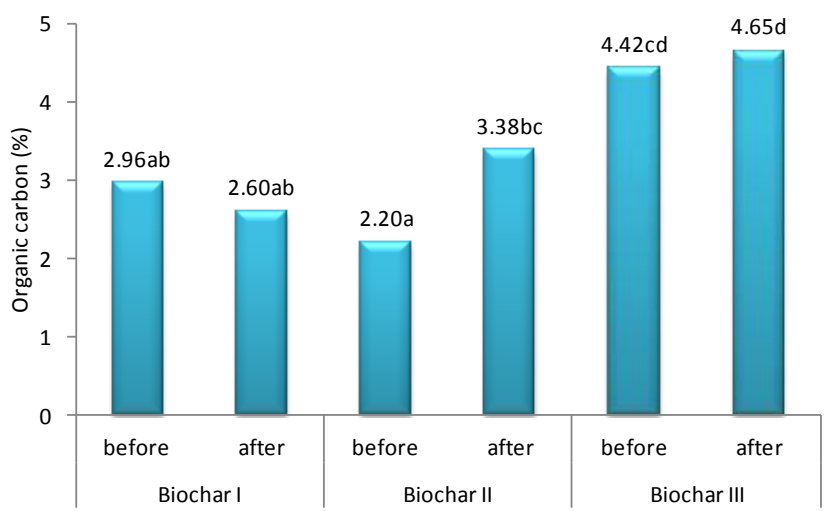

Figure 2. Evolution of organic carbon oxidized with dichromate. Values in columns followed by the same letter are not significantly different $(P=0.05)$ using the Duncan test.

Table 3. Field capacity (FC), wilting point (WP) and available water (AW) after the incubation experiment.

\begin{tabular}{|c|c|c|c|}
\hline & $\mathrm{FC}(\%)$ & $\mathrm{WP}(\%)$ & $\mathrm{AW}(\%)$ \\
\hline $\mathrm{S}$ & $13.54 \mathrm{a}$ & $11.04 \mathrm{a}$ & $2.49 \mathrm{a}$ \\
\hline $\mathrm{S}+\mathrm{BI}$ & $20.41 \mathrm{c}$ & $13.79 \mathrm{c}$ & $6.61 b$ \\
\hline $\mathrm{S}+\mathrm{BII}$ & $20.24 \mathrm{c}$ & $13.91 \mathrm{c}$ & $6.33 b$ \\
\hline $\mathrm{S}+\mathrm{BIII}$ & $16.31 \mathrm{~b}$ & $12.72 b$ & $3.60 \mathrm{a}$ \\
\hline
\end{tabular}

carbon in biochar. Figure 2 shows that BIII, with the highest ash content and the lowest $\mathrm{C}$ content and consequently, expected lowest $\mathrm{CO}_{2}$ emissions, has the highest content of labile, so the $\mathrm{H} / \mathrm{C}$ and $\mathrm{O} / \mathrm{C}$ ratios have shown that $\mathrm{BIII}$ has non-condensed organic structures. After incubation, the labile carbon of BI decreases, whereas that of BII and BIII slightly increases, indicating that some of the more stable organic structures were transformed into labile carbon. This result was in accordance with that obtained previously by Gascó et al. (2012) using thermal analysis and biochar form sewage sludge. However, for BI the labile carbon slightly decreases after incubation.

Results show that biochar addition increased $\mathrm{CO}_{2}$ soil emissions by approximately $25 \%$, but there were no differences between the different treatments (Fig. 3). On the other hand, Zavalloni et al. (2011) found that respiration rates in soil with coppiced woodland-derived biochar were not significantly different from control soil. This matter can be attributed to a combination of different factors, not only to one. Méndez at al. (2013) found that higher $\mathrm{CO}_{2}$ emissions can be related to a higher content of $\mathrm{VM}$ and lower values of ratio $\mathrm{FC} /(\mathrm{FC}+\mathrm{VM})$ from biochars. Also, the $\mathrm{CO}_{2}$ evolved can be related to the labile carbon content of biochars (Fig. 2). On the other hand, different authors (Méndez et al., 2013;

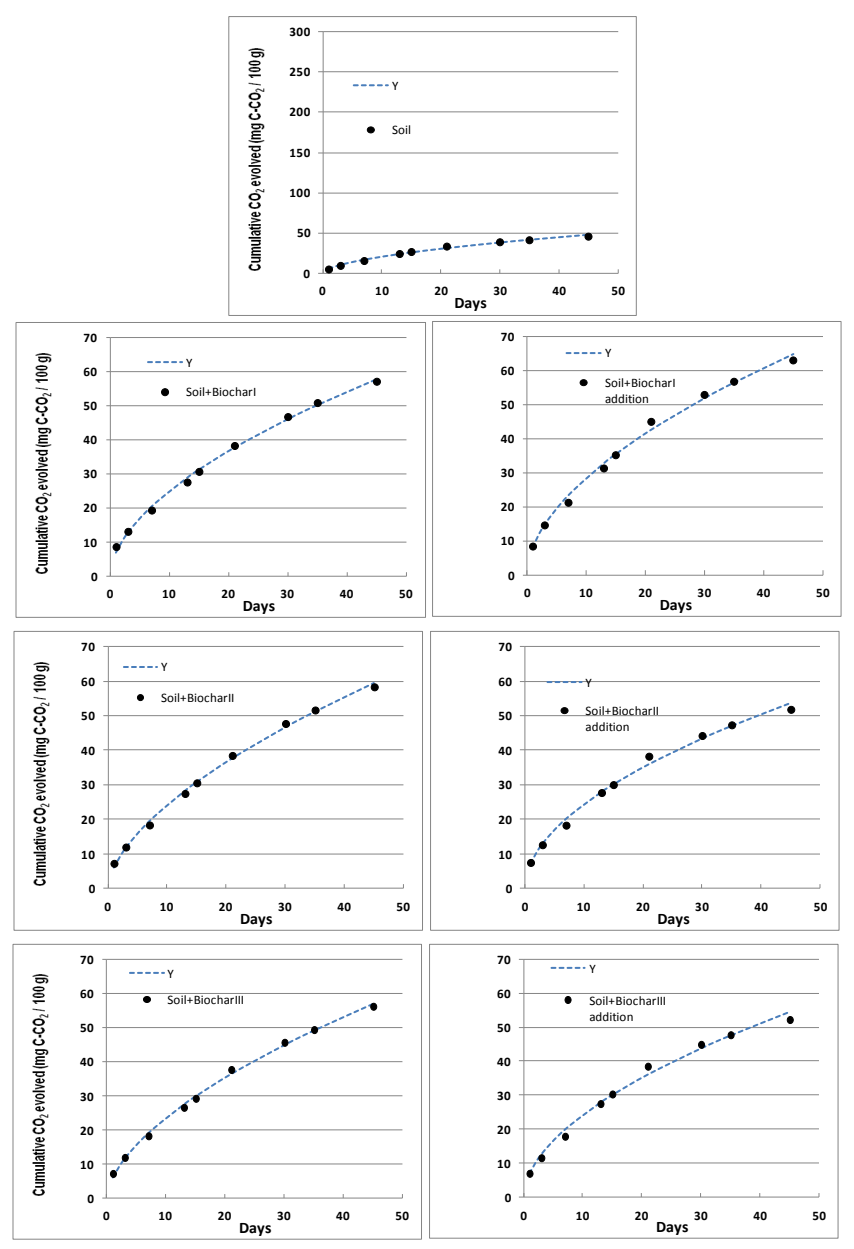

Figure 3. Exponential model of measured $\mathrm{C}$ mineralized (as $\mathrm{CO}_{2}$ ) and that calculated by the addition of soil and BI, BII and BIII effects.

Thies and Rillig, 2009) observed that the reduction in $\mathrm{CO}_{2}$ emissions can be attributed to chemisorptions of the respired $\mathrm{CO}_{2}$ on the biochar surface. Indeed, $\mathrm{BI}$ had a $\mathrm{CO}_{2}$ micropore surface area and $\mathrm{CO}_{2}$ monolayer capacity more than $44 \%$ higher than $\mathrm{BI}$ and $\mathrm{BII}$, so their labile carbon content was lower. Also, $\mathrm{H} / \mathrm{C}, \mathrm{O} / \mathrm{C}$ and $\mathrm{FC} /(\mathrm{FC}+\mathrm{VM})$ ratios indicate that instead of their high carbon content it was a more stable carbon material. Finally, the electrical conductivity, metal and phenolic substances of biochar can have a negative effect on soil microbial activity, reducing the respired $\mathrm{CO}_{2}$. Table 4 summarizes the qualitative influence of different factors on $\mathrm{CO}_{2}$ emissions and it shows an orientation about the influence of different biochar properties on the increment of soil $\mathrm{CO}_{2}$ emissions after biochar application. $\mathrm{pH}$ limits have been fixed following the classes of soil pH of USDA (1998) and the guidelines to biochar production according to Schmidt et al. (2012). It must be pointed out that $\mathrm{pH}$ of 6.6 to 7.3 is favorable for microbial activities that contribute to the availability of nitrogen, sulfur, and phosphorus in soils (USDA, 
Table 4. Influence of different biochar properties on the increment of soil $\mathrm{CO}_{2}$ emissions after biochar application.

\begin{tabular}{lcccccccc}
\hline Value & $\mathrm{pH}$ & $\begin{array}{c}\text { Electrical } \\
\text { conductivity }\end{array}$ & $\begin{array}{c}\text { Organic } \\
\text { carbon }\end{array}$ & $\begin{array}{c}\text { Metal } \\
\text { content }\end{array}$ & $\begin{array}{c}\text { Phenolic } \\
\text { substances }\end{array}$ & $\begin{array}{c}\text { Volatile } \\
\text { matter }\end{array}$ & $\begin{array}{c}\text { Fixed } \\
\text { carbon }\end{array}$ & $\begin{array}{c}\text { BET } \\
\text { surface area }\end{array}$ \\
\hline $\mathrm{High}^{\mathrm{b}}$ & $-\mathrm{a}$ & - & + & - & - & + & + & - \\
$\mathrm{Normal}$ & + & + & + & + & + & + & + & + \\
Low & - & + & - & + & + & - & - & - \\
\hline a $+:$ positive effect; $-:$ negative effect & & &
\end{tabular}

Table 5. $\mathrm{CO}_{2}-\mathrm{C}$ evolved (mg CO $2100 \mathrm{~g}^{-1}$ dry weight) during incubation experiment and parameters estimated according to a simple first-order kinetic model to describe the $C$ mineralization in soil $(S)$, biochars (BI, BII, BIII) and amended soils $(S+\mathrm{BI}, S+\mathrm{BII}, S+\mathrm{BIII})$. Root mean square deviation (RMSD), correlation coefficient $\left(r^{2}\right)$ and coefficient of determination $\left(R^{2}\right)$ of the fitted model are shown.

\begin{tabular}{|c|c|c|c|c|c|c|c|}
\hline Substrate & & $\begin{array}{l}\mathrm{CO}_{2} \text { evolved } \\
\left(\mathrm{mg} \mathrm{C}-\mathrm{CO}_{2} / 100 \mathrm{~g}\right)\end{array}$ & $m$ & $C$ & RMSD & $r^{2}$ & $\begin{array}{l}\mathrm{C}_{10} \mathrm{~b} \\
\left(\mathrm{mg} \mathrm{C}-\mathrm{CO}_{2} / 100 \mathrm{~g}\right)\end{array}$ \\
\hline$S$ & & 45.8 & 0.5524 & 5.81 & 1.23 & 0.996 & 20.72 \\
\hline BI & & 261.2 & 0.5513 & 32.15 & 10.94 & 0.989 & 114.41 \\
\hline BII & & 120.1 & 0.4092 & 25.51 & 6.69 & 0.975 & 65.46 \\
\hline BIII & & 125.6 & 0.5046 & 19.34 & 6.26 & 0.985 & 61.79 \\
\hline \multirow[t]{2}{*}{$S+\mathrm{BI}$} & Experiment & 57.1 & 0.5606 & 6.83 & 0.94 & 0.998 & 24.83 \\
\hline & Addition $^{\mathrm{a}}$ & 63.0 & 0.5521 & 7.91 & 1.34 & 0.997 & 28.22 \\
\hline \multirow[t]{2}{*}{$S+$ BII } & Experiment & 58.3 & 0.5987 & 6.07 & 0.86 & 0.999 & 24.10 \\
\hline & Addition & 51.7 & 0.5262 & 7.22 & 1.22 & 0.997 & 24.25 \\
\hline \multirow[t]{2}{*}{$S+$ BIII } & Experiment & 56.1 & 0.5872 & 6.08 & 0.82 & 0.999 & 23.50 \\
\hline & Addition & 52.2 & 0.5434 & 6.87 & 1.40 & 0.996 & 23.99 \\
\hline
\end{tabular}

a The addition of the experimental data has been made taking into account a dose of $8 \%$.

${ }^{\mathrm{b}} \mathrm{C}_{10}$ is the evolved $\mathrm{CO}_{2}-\mathrm{C}$ after 10 days according the model.

1998), and a $\mathrm{pH}$ value exceeding 10 can have negative effects on soil $\mathrm{pH}$, but it must noted that only the application of larger amounts of biochar will lead to changes in a soil's $\mathrm{pH}$ value (Schmidt et al., 2012). With respect to electrical conductivity, limits have been fixed according to the limits fixed by Richards (1954) where the high value $\left(4 \mathrm{dS} \mathrm{m}^{-1}\right.$, $25^{\circ} \mathrm{C}$ ) is the limit between normal and saline soils. The organic carbon limits have been fixed according to the International Biochar Initiative (2012) and the recommendations of Schmidt et al. (2012), who described that the organic carbon content of pyrolysed chars fluctuates between $10 \%$ and $95 \%$ of the dry mass, depending on the feedstock and process temperature used. With respect to volatile matter (VM) and fixed carbon (FC), values over $20 \%$ and $40 \%$ of VM and FC can be considered high according to biochar prepared from different feedstocks as sewage sludge (Gascó et al., 2012; Méndez et al., 2012), rice husk (Kalderis et al., 2014), euca- lyptus wood or poultry litter (Paz-Ferreiro, 2012; Lu et al., 2014). Finally, BET surface area values should be preferably higher than $150 \mathrm{~m}^{2} \mathrm{~g}^{-1}$ (Schmidt et al., 2012), values over $750 \mathrm{~m}^{2} \mathrm{~g}^{-1}$ being very high and of the same order as montmorillonite. It must stand out that the negative effects are usually due to a combination of different factors and cannot be attributed to a unique factor. Table 5 and Fig. 3 show the parameters estimated according to simple first-order kinetic model to describe the $\mathrm{C}$ mineralization in soil $(\mathrm{S})$, biochars (BI, BII, BIII) and amended soils (S+BI, S+BII, S+BIII). The kinetics of $\mathrm{CO}_{2}$ evolved from biochars was well fit to the proposed model, presenting $r^{2}$ values higher to 0.97 . With respect to the amended soils, the fit presented a root mean square deviation (RSMD) lower than 2 and $r^{2}$ values higher than 0.99. In fact, this model of a simple first-order kinetic model has been successfully used to estimate $\mathrm{CO}_{2}$ emissions 

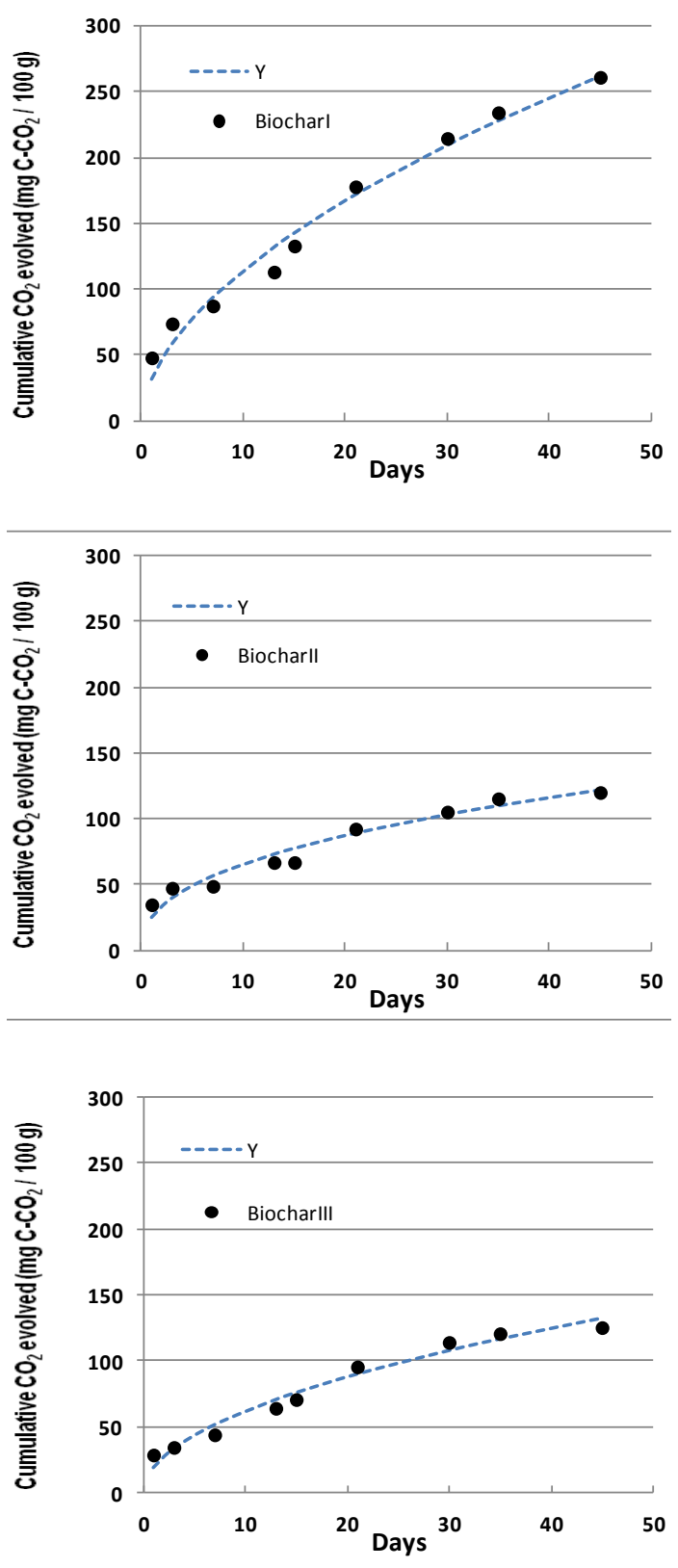

Figure 4. Exponential model of measured $\mathrm{C}$ mineralized (as $\mathrm{CO}_{2}$ ) in BI, BII and BIII biochars.

from biochar and biochar amended soil in a short-term incubation experiment (Méndez et al., 2013).

Also, results show that the application of BI had a negative priming effect if data of the experiment $(57.1 \mathrm{mg} \mathrm{C}-$ $\left.\mathrm{CO}_{2} / 100 \mathrm{~g}\right)$ and addition $\left(63.0 \mathrm{mg} \mathrm{C}-\mathrm{CO}_{2} / 100 \mathrm{~g}\right)$ are compared (Table 4), according with the similar values of model parameters $(m$ and $C)$. This result was in accordance with that obtained by Zimmerman et al. (2011), who found that biochars produced at high temperatures and from hard woods like BI show negative priming. With respect to the application of BII and BIII to soil, results showed a positive priming effect. It is interesting to note that both biochars increase their labile carbon content during individual incubation (Fig. 2), whereas for BI, their content slightly decreases. The initial organic matter mineralization was very similar in all cases (C parameter ranged from 6.07 to 7.91 ) according to Méndez et al. (2012), who found an increment of $\mathrm{CO}_{2}$ emissions after application at the same rate after application of biochar prepared from sludge to a similar sandy soil or results obtained by Smith (2010). Nevertheless, Paz-Ferreiro et al. (2012) found a negative priming effect after sewage sludge biochar application (prepared at $650^{\circ} \mathrm{C}$ ) to an Umbrisol. Indeed, Zimmerman et al. (2011) concluded that discrepancies in $\mathrm{C}$ mineralization of biochar-treated soils are likely due to the type of both soil and biochar, the duration of the experiment and the dose of used biochar.

Finally, the $\mathrm{C}_{10}$ parameter, i.e. evolved $\mathrm{CO}_{2}-\mathrm{C}$ after 10 days according to the model, is related to the labile fraction of biochar to be released by microbial activity. Results show that experimental data were very similar, and the difference between experiment and addition (Table 4) in the case of $\mathrm{S}+\mathrm{BI}$ could suggest a toxic effect of biochar.

\section{Conclusions}

The effect of biochar on the soil carbon mineralization priming effect depends on the characteristics of the raw materials, production method and pyrolysis conditions. Indeed, results show a negative priming effect in the soil after addition of BI (prepared at $620^{\circ} \mathrm{C}$ from a mixed wood sieving from wood chip production) and a positive priming effect in the case of soil amended with BII (prepared at $500^{\circ} \mathrm{C}$ from a mixture of paper sludge and wheat husks) and BIII (prepared at $600^{\circ} \mathrm{C}$ from sewage sludge). These facts can be related to different biochar properties such as carbon content, carbon aromaticity, volatile matter, fixed carbon, easily oxidized organic carbon, metal and phenolic substance content and surface biochar properties. In addition, experimental results show that cumulative $\mathrm{CO}_{2}$ emissions were well fit to a simple first-order kinetic model for the different biochar and amended soils. Also, biochars additionally improved water soil retention. Finally, further research is required to determine the importance of the different biochar properties involved in soil $\mathrm{CO}_{2}$ emissions.

Acknowledgements. We are very grateful to the Delinat Institute for Ecology and Climate Framing (Switzerland) for providing the biochar samples.

Edited by: A. Cerdà 


\section{References}

Barbera, V., Poma, I., Gristina, L., Novara, A., and Egli, M.: Longterm cropping systems and tillage management effects on soil organic carbon stock and steady state level of $\mathrm{C}$ sequestration rates in a semiarid environment, Land Degrad. Dev., 23, 82-91, 2013.

Barriga, S., Méndez, A., Cámara, J., Guerrero, F., and Gascó, G.: Agricultural valorisation of de-inking paper sludge as organic amendment in different soils: thermal study, J. Therm. Anal. Calorim., 99, 981-986, 2010.

Barrow, C.: Biochar: potential for countering land degradation and for improving agriculture, Appl. Geogr., 34, 21-28, 2012.

Bouyoucos, G. J.: Hydrometer method improved for makins paricle size analyses of soil, Agron. J., 54, 464-465, 1962.

Calvelo Pereira, R., Kaal, J., Camps Arbestain, M., Pardo Lorenzo, R., Aitkenhead, W., Hedley, M., Macías, F., Hindmarsh, J., and Maciá-Agulló, J. A.: Contribution to characterisation of Biochar to estimate the labile fraction of carbon, Org. Geochem., 42, 1331-1342, 2011.

Cross, A. and Sohi, S. P.: The priming potential of biochar products in relation to labile carbon contents and soil organic matter status, Soil Biol. Biochem., 43, 2127-2134, 2011.

European Community: Council Directive of 12 June 1986 on the protection of the environment, and in particular of the soil, when sewage sludge is used in agriculture, Directive 86/276/EEC, Official Journal of the European Communities, L 181, 6-12, 1986.

Gascó, G., Paz-Ferreiro, J., and Méndez, A.: Thermal analysis of soil amended with sewage sludge and biochar from sewage sludge pyrolysis, J. Therm. Anal. Calorim., 108, 769-775, 2012.

Hossain, M. K., Strezov, V., Chan, K. Y., Ziokowski, A., and Nelson, P. F.: Influence of pyrolysis temperature on production and nutrient properties of wastewater sludge biochar, J. Environ. Manage., 92, 223-228, 2011.

International Biochar Initiative: Standardized product definition and product testing guidelines for biochar that is used in soil, International Biochar Initiative, Westerville, United States of America, 2012.

Jien, S. H. and Wang, C. S.: Effects of biochar on soil properties and erosion potential in a highly weathered soil, Catena 110, 225233, 2012

Jones, D. L., Murphy, D. V., Khalid, M., Ahmad, W., EdwardsJones, G., and DeLuca, T. H.: Short-term biochar-induced increase in soil $\mathrm{CO}_{2}$ release is both biotically and abiotically mediated, Soil Biol. Biochem., 43, 1723-1731, 2011.

Kalderis, D., Kotti, M. S., Méndez, A., and Gascó, G.: Characterization of hydrochars produced by hydrothermal carbonization of rice husk, Solid Earth Discuss., 6, 657-677, doi:10.5194/sed-6657-2014, 2014.

Kloss, S., Zehetner, F., Oburger, E, Buecker, J., Kitzler, B., Wenzel, W., Wimmer, B., and Soja, G.: Trace element concentrations in leachates and mustard plant tissue (Sinapis alba L.) after biochar application to temperate soil, Sci. Total Environ. 481, 498-508, 2014.

Kuiters, A. T. and Sarink, H. M.: Leaching of phenolic compounds from leaf and needle litter of several deciduous and coniferous trees, Soil Biol. Biochem., 18, 475-480, 1986.

Kuzyakov, Y., Bogomolova, I., and Glaser, B.: Biochar stability in soil: decomposition during eight years and transformation as as- sessed by compound-specific ${ }^{14} \mathrm{C}$ analysis, Soil Biol. Biochem., 70, 229-236, 2014.

Lehmann, J.: A handful of carbon, Nature, 447, 143-144, 2007.

Lehmann, J. and Sohi, S. P.: Comment on "Fire-derived charcoal causes loss of forest humus", Science, 321, 1295 , doi:10.1126/science.1160005, 2008.

Lehmann, J. and Joseph, S. (Eds.): Biochar for Environmental Management: Science and Technology, Earthscan, London, 2009.

Lu, H, Li, Z., Fu, S., Méndez, A., Gascó, G., and Paz-Ferreiro, J.: Can biochar and phytoextractors be jointly used for cadmium remediation? Plos One, 9, e95218, 2014.

Martín-Lara, M. A., Hernáinz, F., Calero, M., Blázquez, G., and Tenorio, G.: Surface chemistry evaluation of some solid wastes from olive-oil industry used for lead removal from aqueous solutions, Biochem. Eng. J., 44, 151-159, 2009.

Méndez, A., Gómez, A., Paz-Ferreiro, J., and Gascó, G.: Effects of biochar from sewage sludge pyrolysis on Mediterranean agricultural soils, Chemosphere, 89, 1354-1359, 2012.

Méndez, A., Tarquis, A., Saa-Requejo, A., Guerrero, F., and Gascó, G.: Influence of pyrolysis temperature on composted sewage sludge biochar priming effect in a loamy soil, Chemosphere, 93, 668-676, 2013.

Nelson, D. and Sommers, L.: Total carbon, organic carbon and organic matter, in: Methods of Soil Analysis, Part 3, Chemical Methods, SSSA, Madison, USA, 1996.

Omuto, C. T., Balint, Z., and Alim, M. S.: A framework for national assessment of land degradation in the drylands: A case study of Somalia, Land Degrad. Dev., 25, 105-119 2014.

Paz-Ferreiro, J., Gascó, G., Gutierrez, B., and Méndez, A.: Soil activities and the geometric mean of enzyme activities after application of sewage sludge and sewage sludge biochar to soil, Biol. Fert. Soils, 48, 512-517, 2012.

Paz-Ferreiro, J., Fu, S., Méndez, A., and Gascó, G.: Interactive effects of biochar and the earthworm Pontoscolex corethrurus on plant productivity and soil enzyme activities, J. Soil. Sediment., 14, 483-494, 2014.

Paz-Ferreiro, J. and Fu, S.: Biological indices for soil quality evaluation: perspectives and limitations, Land Degrad. Dev., doi:10.1002/ldr.2262, 2014.

Plante, A. F., Fernández, J. M., and Leifeld, J.: Application of thermal analysis techniques in soil science, Geoderma, 153, 1-10, 2009.

Rhoades, J. D.: Salinity, Electrical conductivity and total dissolved solids, in: Methods of Soil Analysis, Part 3, Chemical Methods, SSSA, Madison, USA, 1996.

Richards, L. A.: Diagnosis and Improvement of Saline and Alkali Soils, Handbook No. 60, USDA, Washington, USA, 1954.

Schmidt, H. P., Abiven, S., Kammann, C., Glaser, B., Bucheli, T., and Leifeld, J.: Guidelines for biochar production, Delinat Institute und Biochar Science Network, Arbaz, Switzerland, 2012.

Smith, J. L., Collins, H. P., and Bailey, V. L.: The effect of young biochar on soil respiration, Soil Biol. Biochem., 42, 2345-2347, 2010.

Sohi, S. P., Krull, E., Lopez-Capel, E., and Bol, R.: A review of biochar and its use and function in soil, Adv. Agron., 105, 47$82,2010$.

Srinivasarao, C. H., Venkateswarlu, B., Lal, R., Singh, A. K., Kundu, S., Vittal, K. P. R., Patel, J. J., and Patel, M. M.:Longterm manuring and fertilizer effects on depletion of soil organic 
carbon stocks under pearl millet-cluster bean-castor rotation in Western India, Land Degrad. Dev., 25, 173-183, 2014.

Sumner, M. and Miller, W.: Cation exchange capacity and exchange coefficients, in: Methods of Soil Analysis, Part 3, Chemical Methods, SSSA, Madison, USA, 1996.

Thies, J. E. and Rillig, M. C.: Characteristics of biochar: biological properties, in: Biochar for Environmental Management: Science and Technology, Earthscan, London, 2009.

Thomas, G. W.: Soil pH and soil acidity, in: Methods of Soil Analysis, Part 3, Chemical Methods, SSSA, Madison, USA, 1996.

USDA: Soil QualityTest Kit Guide, USDA, Washington, USA, 1999.

USEPA: Method 3051a: microwave assisted acid dissolution of sediments, sludges, soils, and oils, USDA, Washington, USA, 1997.

Wardle, D. A., Nilsson, M. C., and Zackrisson, O.: Fire-derived charcoal causes loss of forest humus, Science, 320, 5876, doi:10.1126/science.1154960, 2008.
Yan-Gui, S., Xin-Rong, L., Ying-Wu, C., Zhi-Shan, Z., and Yan, L.: Carbon fixaton of cyanobacterial-algal crusts after desert fixation and its implication to soil organic matter accumulation in Desert, Land Degrad. Dev., 24, 342-349, 2013.

Zavalloni, C., Alberti, G., Biasiol, S., Delle Vedove, G., Fornasier, F., Liu, J., and Peressotti, A.: Microbial mineralization of biochar and wheat straw mixture in soil: a short-term study, Appl. Soil Ecol., 50, 45-51, 2011.

Zhao, G., Mu, X., Wen, Z., Wang, F., and Gao, P.: Soil erosion, conservation, and Eco-environment changes in the Loess Plateau of China, Land Degrad. Dev., 24, 499-510, 2013.

Zimmerman, A. R., Gao, B., and Ahn, M.: Positive and negative carbon mineralization priming effects among a variety of biochar amended soils, Soil Biol. Biochem., 43, 1169-1179, 2011. 